\title{
A IX Conferência Nacional de Saúde
}

\author{
Paulo Marchiori Buss \\ Diretor da Ensp/Fiocruz
}

A IX Conferência Nacional de Saúde é mais uma oportunidade democrática para o amplo debate sobre este crítico setor saúde no Brasil. Está convocada para novembro deste ano, em Brasília. E estará ocorrendo num momento particularmente difícil da vida nacional, na qual a recessão e o desemprego provavelmente agravarão, de forma dramática, a situação de saúde dos segmentos mais vulneráveis da população.

A questão da saúde no nosso país, aliás, tem historicamente contornos dramáticos. De setor marginalizado e negligenciado até, pelo menos, a década de 60 , vem adquirindo importância crescente nos últimos 20-30 anos. De fato, o surto de desenvolvimento econômico do período autoritário trouxe consigo o surgimento de uma enorme Previdência Social, a assistência médica passou a ser um segmento importante de acumulação de capital e, mais recentemente, com o processo da redemocratização, a questão da saúde passa a ser pauta de reivindicação nas negociações trabalhistas e aspiração da cidadania, de maneira geral.

Simultaneamente, o mesmo desenvolvimento econômico, com seu modelo aético, concentrador e excludente, tornou dramáticas também as condições de vida e saúde. A distribuição desigual das riquezas, bens e serviços criou dois (ou muitos) brasis: um, minoritário, moderno e capaz de acessar todas as benesses do desenvolvimento, inclusive os mais sofisticados recursos tecnológicos em saúde, com índices sanitários invejáveis, ao nivel da Dinamarca; e outro, o imenso Brasil da miséria, da desnutrição, da desesperança, das péssimas condições de vida e saúde, ao nível dos mais miseráveis e atrasados países do mundo.

$\mathrm{Na}$ média, melhoraram os indicadores de saúde. Mas permanecem as diferenças abismais nas condições de saúde e acesso a bens e serviços sanitários entre grupos sociais, regiões, segmentos populacionais.

Toda a discussão que a questão da saúde vem despertando na sociedade brasileira diz respeito tanto aos interessados (e às necessidades) dos setores dominantes da sociedade - que precisa de gente saudável produzindo e consumindo, 
inclusive bens e serviços, no interior do setor saúde -, quanto aos interesses (e necessidades) dos segmentos populares, relacionados com a ampliação da noção de direitos de cidadania.

Uma série de tentativas de reformas, adaptação, ajustes, vem sendo tentada no sistema de atenção à saúde do país, ao longo dos anos, como respostas a estes movimentos e aspirações. E o elenco de medidas jurídico-legais vem, também, se alterando em função do debate na sociedade.

A VIII Conferência Nacional de Saúde, realizada em 1986, foi, neste sentido, um acontecimento exemplar. Reunindo quase 5.000 pessoas em Brasilia, num processo que, começando nos municípios, envolveu quase $50 \mathrm{mil}$ pessoas, foi um coroamento de alguns anos de debate. Definiu a saúde como direito do cidadão e dever do Estado e lançou as bases politicas e técnicas para o debate sobre saúde na Constituinte. O resultado foi um texto constitucional sobre saúde moderno e abrangente, um dos mais avançados do mundo, na Constituição Brasileira de 1988. Seguiram-se as Constituições Estaduais de Saúde e as Leis Orgânicas dos Municípios, com seu componente sanitário. Os textos obtidos pela mobilização da sociedade variaram de caso a caso, conforme a configuração política das respectivas Assembléias Legislativas e Câmaras Municipais. Em todos os casos, pode-se afirmar que, em geral, os produtos obtidos são bons e suficientemente abrangentes para não se constituírem em obstáculos ao desenvolvimento do setor; ao contrário, são estimulantes e, se bem utilizados, orientadores da ação.

Do ponto de vista dos movimentos de reordenamento do setor, o SUDS, iniciado em 1987, representou um movimento de nítida descentralização, todavia ainda não concluído, e a Lei do Sistema Único de Saúde, já em 1990, fixou as bases para novas relaçōes entre os três niveis de governo, além de estabelecer as regras básicas para o setor, em diversas dimensões.

Entretanto, toda a magnitude do debate sobre saúde na sociedade, sua expressão nos parlamentos, a importância real da saúde na vida concreta das pessoas e os avanços jurídico-legais não lograram o que talvez mais interessa a todos: um sistema de saúde que efetivamente funcione, humano e equitativo, que de fato promova a saúde, previna e cure as enfermidades. Um sistema de atenção à saúde confiável, com custos compativeis com a capacidade da sociedade brasileira. 
Chegamos, assim, à conjuntura da IX Conferência Nacional de Saúde com uma série de indagações a respeito dos processos vividos e vindouros. Trata-se de um momento de inflexão de todo o processo social e político dos últimos anos, batizado de Reforma Sanitária e que terá um momento muito importante na IX Conferência. Esta Conferência tem a tarefa de tomar os parâmetros já definidos por todo o processo da Reforma - incluindo os textos legais e apontar políticas e medidas concretas destinadas à superação das questōes de saúde que fazem parte do dia-a-dia do cidadão, que hoje está saturado dos discursos e de conquistas de leis que não mudam de fato a sua qualidade de vida.

Cremos, por isso mesmo, que a Conferência deve partir de um conceito ampliado de saúde e do resgate do caráter público do Estado, qualquer que seja o nível considerado, mas principalmente o Município.

Isto significa a formulação e aplicação de verdadeiras politicas sociais saudáveis. Vale dizer, a articulação de políticas de saúde, educação e saneamento (água, esgoto e lixo), pelo menos, formuladas com participação da população organizada e aplicada sob seu controle. Somente a articulação das ações públicas desses setores será capaz de causar algum impacto e promover um incremento na qualidade de vida.

Para isto, há a necessidade do desenvolvimento institucional dos municípios, dando-lhes competência para a formulação e execução dessas políticas sociais. O planejamento estratégico é uma ferramenta poderosa à disposição desses interesses e objetivos.

No campo específico da assistência médica, algumas posições políticas precisarão ser consolidadas na Conferência que se propõe a indicar a municipalização como o caminho para a saúde:

1. A constituição do comando político e técnico único a nível municipal, inclusive com a unificação do sistema público no Município e a gestão do sistema local de saúde, inclusive a relação com hospitais e demais ações de saúde de abrangência individual ou coletiva.

2. O repasse automático de recursos financeiros federais e estaduais correspondentes e necessários às nossas responsabilidades delegadas ao município, pois sem isto não haverá descentralização efetiva do poder.

3. O claro equacionamento de políticas nacionais. Vale dizer que independem do nível municipal, mas que Cadernos de Saúde Pública, RJ, 7(3): 297-300, jul/set, 1991 
refletem poderosamente sobre ele: recursos humanos, fármacos e equipamentos, pelo menos.

4. A construção de políticas e planos municipais de saúde amplamente debatidos e aprovados, que se articulem com as demais políticas sociais, representando compromissos políticos claros do executivo com o legislativo municipal, o Conselho de Saúde e a população em geral.

5. A definição precisa dos papéis e compromissos de cada nível de governo.

O Município, como célula mínima de estrutura político-administrativa brasileira, é teoricamente capaz de organizar um sistema de saúde mais adequado às necessidades de seus habitantes, por encontrar-se mais próximo do espaço concreto onde vivem as pessoas e mais sensível às pressões e reivindicações da população. Trata-se, na prática, de demonstrar isto. E a IX Conferência é um espaço político da maior importância para a reafirmação de princípios e a construção de pactos capazes de contribuir para a constituição de um sistema de saúde integral único, de base municipal, eficiente e com claro compromisso social. 